\title{
O Martírio da filosofia
}

FELIPE RAMOS GALL *

* Doutorando em Filosofia pela PUC-Rio

Bolsista CAPES
RESUMO Trata-se de uma tentativa de descrição fenomenológica da experiência do filosofar, da filosofia que se apresenta e aparece como martírio. Martírio que é sacrifício, mas que também é testemunhar. A imbricação dessas noções é o que aqui nos move, ainda que nos movamos de modo claudicante, coxeando entre fragmentos esparsos. Tacitamente, percorre no texto uma compreensão do pensamento de Martin Heidegger, visando explorar as noções de cotidianidade e propriedade, existência, finitude, morte e verdade. Essas noções aparecem apoiadas na literatura e nas Sagradas Escrituras, bem como em imagens poéticas, pressupondo uma ideia de filosofia não estritamente acadêmica. O que se busca é falar da filosofia como vocação, e não como profissão. Enquanto vocação, ela é um chamado para o agir, para a ação que, embora tida como inútil, paradoxalmente é necessária, pois é vital. Consumar a existência, almejar a plenitude, levar a cabo o que temos de próprio, nossa essência: isso é a ação em sentido mais elevado, é o tempo se fazendo tempo, é a vida se fazendo vida. Filosofia é a vida da vida.

PALAVRAS-ChaVe Filosofia; Martírio; Vida; Ação 
Dedico este texto a Gilvan Fogel.

Eм uma crônica datada de 26 de julho de $1896^{1}$, Machado de Assis exclama uma boa-nova: que se apague a lanterna de Diógenes, pois encontrou um homem. Homem que "não é príncipe, nem eclesiástico, nem filósofo, não pintou uma grande tela, não escreveu um belo livro, não descobriu nenhuma lei científica", mas sim "um homem que, sendo barbeiro, não era exatamente barbeiro”. Ocorre que Machado se deparou com este anúncio no jornal: "Vende-se uma casa de barbeiro fora da cidade, o ponto é bom e o capital diminuto; o dono vende por não entender... do ofício”. A magnanimidade do homem tornou-se manifesta quando ele se deu conta de que não bastava apenas imitar o que ele via outros barbeiros fazendo, teria que realmente entender do ofício, ter nascido para aquilo. Seu caráter único, motivo do assombro de Machado, foi o de ter sido sincero quanto a sua vocação. Podiam apontar para ele na rua e falar que aquele era “o barbeiro da rua tal”, mas ele, em seu âmago, sabia que era uma farsa. Desempenhava um papel no teatro da vida para o qual não tinha o menor preparo, não chegou nem a dar uma lida apressada no script. A nobreza dessa sinceridade vital, se fosse compartilhada, "retificaria toda a sociedade", no dizer de Machado. Essa ideia não está muito afastada do que Sócrates diz na República, onde, para manter a unidade não só da cidade, como de cada indivíduo, cada cidadão deveria ser encaminhado para a atividade própria para qual nasceu, e nenhuma outra ${ }^{2}$. Tal é o fundamento da justiça na cidade.

São Paulo inicia a sua Epístola aos Romanos, um dos textos basilares e, por conseguinte, mais significativos do Ocidente, com a seguinte frase: "Paulo, servo de Cristo Jesus, chamado a ser Apóstolo, escolhido para anunciar o Evangelho de Deus”3. O texto pau-

1 Disponível em :

http://www.cronicas.uerj.br/home/cronicas/machado/rio_de_janeiro/ano1896/26jul1896.html

2 PLATÃO, República, 423d.

$3 R \operatorname{Ri:1.}$ 


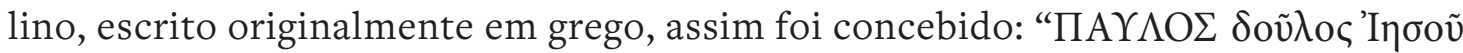
X Khristõu, kletòs apóstolos, aphorisménos eis euangélion theõu)”. Um único termo desta apresentação nos interessa aqui: chamado, $\kappa \lambda \eta \tau$ tó (kletós), que São Jerônimo, na

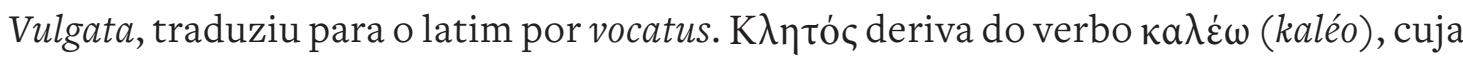
polissemia diz chamar, convocar, invocar, convidar, requerer, exigir. K $\lambda \eta \tau$ có, assim, é o chamado, o convocado, o escolhido, o eleito. A tradução latina por vocatus é precisa, pois significa o mesmo que $\kappa \lambda \eta \tau$ т́ৎ - ou seja, chamado, convocado etc. - como também pode significar nomeado, designado. Nossa palavra vocação deriva deste termo.

É comum nossas escolas proporem aos jovens testes vocacionais, a fim de ajudá-los a descobrir qual melhor profissão se adequaria às suas aptidões. Muitas vezes, pessoas largam seus empregos que, embora pudessem ser bem remunerados, não as satisfaziam profissionalmente, dizendo: “não tinha vocação para isso”. Contudo, seriam estes testes realmente capazes de determinar as vocações das pessoas? Ou ao menos sugestionar? Analisa-se Fulano. Ele tem "facilidade" com as humanidades em geral, história, literatura, sociologia etc. Estaria apto, então, a ser um professor, bibliotecário ou advogado; Ciclano, por sua vez, não apresenta as dificuldades que normalmente os demais jovens têm com matemática: ele estaria apto, assim, a ser um engenheiro; Beltrano "leva jeito" para biologia, seria um bom médico, e assim por diante. Cada jovem, no momento crítico da escolha de sua carreira, no nosso caso, no término do Ensino Médio, é enquadrado em alguma aptidão genérica de acordo com seu histórico escolar, e deve prestar o vestibular em conformidade com isso. Trata-se de uma exigência de nossa sociedade de mercado, que exige, inclusive, que alguns jovens, que ou por falta de oportunidade ou por, aparentemente, não possuírem "talento algum”, devam ser alocados ao setor de serviços, comércio, trabalhos informais, biscates ou coisas do tipo. Não é possível que todos sigam suas vocações, talvez nem seja possível que todos possam ter vocações.

Seria o chamado, a vocação de Paulo, algo do tipo? Ele prestou algum teste vocacional que indicou que ele teria talento, que ele "levaria jeito", para ser apóstolo? Evidentemente não. Mas não podemos afirmar ainda que não haja nenhum resquício desse sentido mais profundo de vocação em nossa compreensão hodierna do texto. Decisiva para essa secularização da $\kappa \lambda \eta \tau$ có paulina foi sua tradução por Beruf no alemão, realizada por Lutero. Embora possua uma relação etimológica com o verbo rufen, cha- 
mar, Beruf, mais do que vocação, deu um sentido de profissão para o $\kappa \lambda \eta \tau$ tó de Paulo. Essa transformação de sentido não passou despercebida a Max Weber, justamente como um dos pontos de apoio para a tese de sua monumental obra A ética protestante e o espírito do capitalismo, de 1904. Quanto a isso, diz-nos Agamben:

O que ele chama de "espírito do capitalismo" - isto é, a mentalidade que faz do próprio lucro um bem, independentemente das suas motivações hedonistas ou utilitárias - teria origem na ascese profissional calvinista e puritana, emancipada de seu fundamento religioso. Isso significa, em outras palavras, que o espírito capitalista é uma secularização da ética puritana da profissão. Mas esta (...) se constrói, por sua vez, justamente a partir da passagem paulina sobre a klêsis (...), transformando a vocação messiânica que nela está em questão no conceito moderno de Beruf, ao mesmo tempo vocação e profissão mundana ${ }^{4}$.

A passagem paulina sobre a $\kappa \lambda \tilde{\eta} \sigma \iota \varsigma$ (klêsis) supramencionada por Agamben encontra-se na Primeira Epístola aos Coríntios: "Cada um fique na vocação em que foi chamado"5.

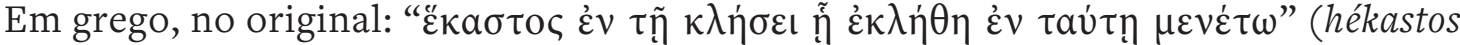
en tê klései hé ekléthe en táute menéto). O próprio sentido de Igreja, para Paulo, estaria relacionado a isso. Ele diz: "E assim cada um ande como Deus lhe repartiu, cada um

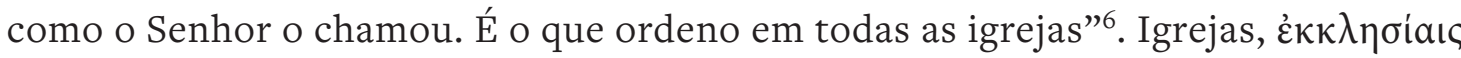
(ekklesíais), tem uma relação semântica com a vocação aqui aludida, no sentido de que $\dot{\varepsilon} \kappa \kappa \lambda \eta \sigma i a(e k k l e s i ́ a)$ vem de $\dot{\varepsilon} \kappa(e k)$, para fora, a partir de, e $\kappa a \lambda \dot{\varepsilon} \omega$, verbo que, como visto, dá origem a $\kappa \lambda \eta \tau$ có. A igreja paulina, por conseguinte, seria a reunião desses chamados, de todas as pessoas que despertam para a sua vocação própria.

Vocação não é profissão, mas sim aquela tarefa, aquela atividade que faz da vida, Vida. Isso é agir propriamente. Mais que imaginar que sua vontade, seu “eu” ou sua consciência é causa e que a atividade resultante é um efeito, agir propriamente é não só levar a vida, a vida banal e cotidiana, mas elevar a vida, levá-la à sua plenitude, sua consu-

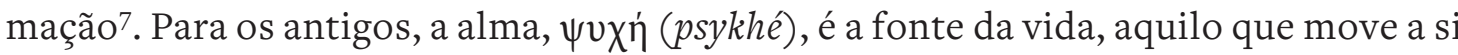

\footnotetext{
4 AGAMBEN, O tempo que resta, p. 34.

$51 \operatorname{Cor} 7: 20$.

61 Cor $7: 17$.

7 Cf. HEIDEGGER, Carta sobre o humanismo, p. 326. In: Marcas do caminho.
} 
próprio $^{8}$ : a natureza da alma é movimento, logo, ação, atividade. Movimento, ensina Aristóteles, é a atualização de uma potência. Atualizar, de ato, actus, tradução latina

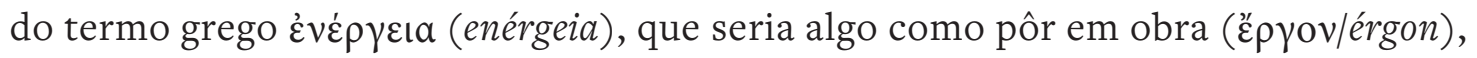
daí significando atividade, operação. A alma é ato diz: a vida, a existência é atividade, é a દ̉vé $\rho \gamma \varepsilon ı$ a enquanto a energia que propicia a meta, o pôr-se a caminho da perfeição, da $\varepsilon \dot{v} \tau \lambda \dot{\varepsilon} \chi \varepsilon ı$ (entelékheia). Esse é o nosso método: capacidade de perfeição. Aristóte-

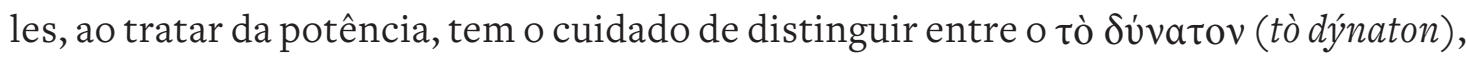

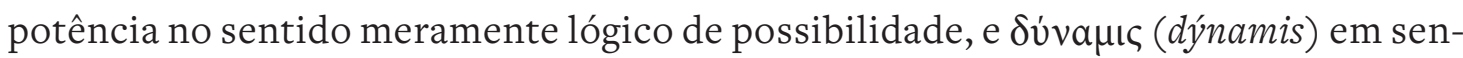
tido próprio, capacidade. A madeira do carvalho tem muitas possibilidades abstratas, pode ser mesa, cadeira ou cama, mas o carvalho, por si próprio, só pode ser carvalho: desde que era uma semente, a capacidade própria dela era a de ser carvalho, nada mais, nada menos. Essa capacidade está dada para todos os entes vivos, menos para o homem: cabe ao homem se fazer homem, o ser-homem do homem não é dado de

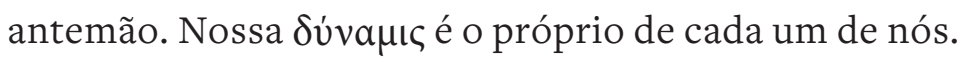

Ao simples cozinheiro de um templo budista que dizia que não era capaz de praticar artes marciais, pois isso estava muito além de suas capacidades, o Mestre Zen responde que também o cozinhar é um caminho para a iluminação. O princípio é o mesmo: o ato deve vir do coração, não da consciência. Qualquer caminho, por mais estreito e pobre que seja, é um caminho para o Grande Caminho. Mas o Grande Caminho não se encontra em nenhum mapa, para ele ninguém pode apontar a direção. Para aqueles capazes de fazer o seu próprio caminho no caminhar mesmo, o seu caminho e o Grande Caminho coincidem. Todavia, não poucas vezes optamos por seguir um caminho dado, já pronto, percorrido sem amor, sem o coração a bater na sola dos pés, que não leva a lugar algum. O Grande Caminho sempre vai surgir no portal do instante, que abre o eterno círculo da vida. Todo ponto é começo possível e nenhum ponto é propriamente começo, pois o círculo retorna eternamente para o instante que o funda.

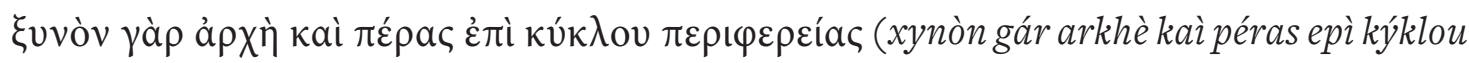
peripheréias), "princípio e fim se reúnem na circunferência do círculo”, diz Heráclito

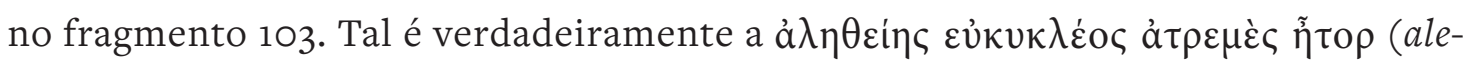

8 Cf. PLATÃO, Fedro, 245 e ss.

9 HERÁCLITO, fr. 103. In: Os pensadores originários, p. 99. 
théies eukykléos atremès êtor), a verdade de circularidade perfeita do coração intrépido, de que nos fala Parmênides ${ }^{10}$.

Divagamos. A questão que nos toca aqui é acerca do caminho do filósofo. O que é filosofar? - uma pergunta tão antiga quanto a filosofia mesma. Filosofar sempre foi um martírio, mas contemporaneamente essa expressão ganhou uma conotação mais específica. Nas sociedades capitalistas de hoje, onde a vocação se reduz a um cargo profissional e a busca por trilhar seu caminho próprio dá lugar ao empreendedor de si mesmo, ao self-made man, que procura meramente galgar seu lugar no mercado de trabalho, visando promoções e cargos mais elevados, entendendo por isso cargos que dêem mais dinheiro, o lento e claudicante andar característico da filosofia é tido como coisa de idiota. Filosofia não serve para nada, não é servil, serviçal da sociedade de consumo (quer dizer, até passou a ser, quando foi transformada em mera erudição chique, aí ela serve para impressionar os menos doutos na academia - de ensino e de ginástica). Nesse sentido, estudar filosofia é martirizante porque é um nadar contra a corrente, e como tal vai necessariamente enfrentar o confronto dos que atravessam o rio da vida boiando, e não a nado. Boiar aqui é deixar a correnteza da vida nos levar pelo caminho que houver, desde que não seja muito cansativo ou doloroso. Talvez na iminência da mortal cachoeira ele passe a se debater e estrebuchar, almejando de algum modo ser salvo, mas como sempre já é tarde demais, ele se contenta em se convencer de que boiar valeu a pena, e se entrega à violenta queda.

E para onde nada o filósofo? Para a margem, ele busca estar à margem. Filosofia, pensamento, é sempre marginal. O esforço dela é se manter e se ater à margem, suportando o puxar da correnteza. Não se pode deixar o rio, sair do rio - que na nossa metáfora aqui é a vida - por isso não dá para viver na margem em si, fora do fluxo, porque esse "fora” não existe. Cedo ou tarde há de se largar e recair na lassidão e letargia que é seguir a corrente, como todos os seres, mas sem deixar de namorar a margem, sem deixar de a querer ter, possuir. Numa carta datada de 14 de abril de 1888 para Carl Fuchs, Nietzsche, em Turim, revela um desejo seu, que a paisagem italiana acentua: ser “(...) Nur Philosoph! Nur abseits! Nur kompromittierend ab-

10 PARMÊNIDES, fr. 1, tradução proposta por E. Carneiro Leão, mimeo. 
seits! - (...)"11, isto é, ser “Apenas filósofo! Apenas à margem! Apenas comprometidamente à margem!”. No comprometimento revela-se o enamorado, sempre fiél. São as margens que fazem o rio. A margem é o que delimita, dá fim. Querer pôr-se à margem é não apenas aceitar o limite, mas desejar a finitude, com sinceridade e leveza de coração. Por isso que o amor fati, bem entendido, não é nem nunca pode ser resignação. Alguém que desdenha do esforço de nadar em direção à margem poderia averiguar com correção que tanto quem nada, quanto quem boia, no final tem o mesmo fim. Ele nada para nada. Afinal de contas, o rio nunca para. De fato, se olharmos para o brutum factum, dá no mesmo. No entanto, concluir disso que, então, nada vale a pena, é já estar boiando. A resignação é uma das faces da vingança contra a vida, mais especificamente contra a finitude desta. Por quê ou para quê fazer, se, no fim, a vida desfaz? Paradoxalmente, vital aqui é a relação com a morte, aprender a morrer, a largar e a abrir mão, sem avareza ou mesquinharia. Passar da ingratidão à generosidade, pois só é verdadeiramente generoso quem é magnânimo - dotado de grande alma (grande vida!). Assim, para o magnânimo, o pouco sobra, transborda. Lembremos que na Parábola dos Talentos ${ }^{12}$, o servo que recebeu apenas um talento, o que ele achou que era muito pouco quando comparado com os outros, por medo de perdê-lo resolveu enterrá-lo, sendo depois punido por isso. Medo de arriscar, medo do perigo. É o medo da vida que impede a travessia.

Tive medo. Sabe? Tudo foi isso: tive medo! Enxerguei os confins do rio, do outro lado. Longe, longe, com que prazo se ir até lá? Medo e vergonha. A aguagem bruta, traiçoeira - o rio é cheio de baques, modos moles, de esfrio, e uns sussurros de desamparo. (...) Quieto, composto, confronte, o menino me via. - "Carece de ter coragem...” - ele me disse. Visse que vinham minhas lágrimas? Dói de responder: - "Eu não sei nadar...” O menino sorriu bonito. Afiançou: - “Eu também não sei”. Sereno, sereno. $[\ldots]^{13}$

O medo do rio que Riobaldo tinha por não saber nadar é o medo da vida por não saber viver. Saber viver - alguém realmente o sabe? O menino Reinaldo o tranquilizou, e serenamente disse que também não sabia. Riobaldo, ao perceber que o rio não queria nada (rio-baldio), que não queria matar ou salvar, destruir ou construir, que o rio era

11 NIETZSCHE, Briefe, III, \$233, p. 880.

12 Mt. 25:14-30

13 ROSA, Grande Sertão: Veredas, pp. 88-89. 
apenas o fluxo perene da vida, passou a ter uma "vergonha de outra natureza", uma vergonha da vergonha que antes havia tido. Coragem, segundo os antigos, é uma perseverança quanto ao que realmente se deve temer. E o que realmente se deve temer não é a perda da vida, e sim nunca ter Vivido. Porque viver não é preciso, já diziam os marinheiros antigos: somente o navegar é preciso. E o navegar é o caminho de cada um, a travessia de cada um, a busca pela margem de cada um. A humanidade sempre se dividirá entre os que se esforçam e se sacrificam pelo inútil necessário, que aos ouvidos do senso comum é um paradoxo, e os que se ocupam e estão sempre preocupados em servir, em querer ser útil de qualquer maneira. O inútil também serve, com a diferença de que ele serve apenas à vida, presta obediência apenas à mais exigente e digna das senhoras. Por isso que ainda ecoa até hoje aquela admoestação de Cristo a uma Marta que, diante do divino, só se preocupava com a diligência das tarefas mundanas, enquanto uma Maria amorosa e supérflua sentava a seus pés para o ouvir, com toda a atenção. "Marta, Marta, só uma coisa é necessária”14.

Nessa perspectiva, a filosofia é exemplar. É aquele caminho que ilumina os demais caminhos. Filosofia é a vida da vida, o ver que se vê. Até mesmo o cozinhar conduz a iluminação, e essa iluminação é a filosofia. Toda ação própria vai ver a filosofia como parâmetro. Não há aqui um juízo de valor, pois não se está dizendo que fazer filosofia é uma atividade superior ou mais importante. Está se dizendo que qualquer ação, em sentido próprio, é de certo modo filosofia. Porque a filosofia é a "ciência”, a busca, pelo ser, pelo sentido de ser. E o ser é o verbo dos verbos, pois qualquer outro verbo, isto é, qualquer ação-tempo, no fundo é ser. Cozinhar é ser-cozinheiro, pescar é ser-pescador, lecionar é ser-professor. Quando a ação é autêntica, há uma identificação absoluta entre o verbo da ação e o ser. Para o velho Santiago de O velho e o mar, ser-pescador e ser dizem o mesmo. Quem dera ele pudesse ser outra coisa, mas ele nasceu para isso - nasceu, despertou para o pescar. Nascer pra isso não significa que o ser pescador já estava no DNA dele, que ele está predestinado a pescar, que ele é um joguete de um fatalismo. Despertar é abrir os olhos para o que já sempre estava aí. Santiago, pescar e ser confluem no rio da vida. Não-pescar é, para ele, não-ser. Não-ser que também faz parte da vida. Não-ser é o ente, as coisas mundanas de nossa vida fática, que compõem nosso mundo, nossa estrutura, inescapável. A diferença é que o

14 Lc. 10:41. 
mundo cotidiano é visto por Santiago com olhos de pescador, é visto por Rodin com olhos de escultor, e é visto por Van Gogh com olhos de pintor. O mundo mesmo, em si, não há. Há os horizontes, os sentidos, que dão a ver quem apruma a visão, a quem sabe ver, ver o visível se mostrando como tal. Não por acaso o бọóc (sophós), o sábio, é quem é apto, capaz de saborear, dotado de um paladar apurado. Sapere é sapore. Por isso Alberto Caeiro, o Übermensch, é o mestre de todos os heterônimos pessoanos, bem como o mestre de todos que desejam saborear a vida:

Sou um guardador de rebanhos./O rebanho é os meus pensamentos/E os meus pensamentos são todos sensações./Penso com os olhos e com os ouvidos/E com as mãos e os pés/E com o nariz e a boca./Pensar uma flor é vê-la e cheirá-la/E comer um fruto é saber-lhe o sentido.

Por isso quando num dia de calor/Me sinto triste de gozá-lo tanto,/E me deito ao comprido na erva,/E fecho os olhos quentes,/Sinto todo o meu corpo deitado na realidade,/Sei a verdade e sou feliz ${ }^{15}$.

Aprender a ver, a sentir, é filosofar. Amar o saber, amar o sabor da existência, querer isso de todo coração. O ser apenas filósofo almejado por Nietzsche, que é pôr-se e dispor-se comprometidamente à margem, é para prestar testemunho da vida, do espantoso milagre da existência. Morrer para a vida banal e cotidiana, de modo a Viver. Por isso filosofia é martírio, é sacrifício mas também é um testemunhar, sentido

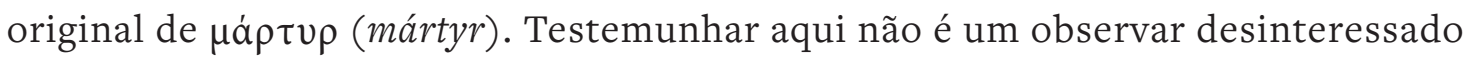
que apenas relata e notifica fatos, não é coisa de jornalista vulgar nem de fofoqueiro. É um comprometimento vital, ativo, com a maravilha do sagrado, com a gratuidade da existência. Reza a lenda que Rodin lia A imitação de Cristo, de Tomás de Kempis, substituindo “Cristo” por "Escultura” - a arte é a imitação, a mímesis do sagrado. O sagrado é o que orienta o artista, o criador, e o Oriente é o lugar do nascimento, da gênese. Conhecer é co-nascer, é participar da gênese ${ }^{16}$, e por isso conhecer algo é criar. Só conhece quem faz. Conquista-se assim o direito de se falar sobre a obra, sem recair em intelectualismo ou erudição vazia. Como assevera Zaratustra, o porta-voz da vida: "De tudo escrito, amo apenas o que se escreve com o próprio sangue. Escreve

15 PESSOA, Poesia completa de Alberto Caeiro, O guardador de rebanhos, IX, p. 34.

16 Vemos em Homero que o conhecimento dos deuses sempre depende de uma afinidade para com eles, como por exemplo Odisseu e Palas Atena, partícipes de Mìtıৎ (Métis), astúcia. 
com sangue: e verás que sangue é espírito. Não é coisa fácil compreender o sangue alheio: eu detesto os que leem por passatempo"17.

Sendo mártir, testemunha do sagrado, o filósofo recusa a sucessão corriqueira dos fatos, ele não se pretende historiador. Ele se põe à margem de modo a se distanciar do mundo da vida, da publicidade, pois só assim é possível uma relação com seu próprio tempo, com a gênese ontológica de todo agir, fazer e acontecer. Aristóteles presta testemunho de que a vida do filósofo, sua felicidade mais elevada, se dá no instante de contemplação do divino, que rompe com a linearidade do tempo e salta para o círculo do pensamento de pensamento. O pôr-se à margem é essa ruptura. Não é ensimesmamento ou solidão fática: é um estar fora que é dentro e desde dentro. Solidão vital é finitização, ver-se, pôr-se e dispor-se como finito, e não isolamento. Filosofar é trazer à luz uma experiência, um próprio - uma força, diria Nietzsche. Essa experiência é o tempo se fazendo tempo, o desdobramento da finitude posta em jogo, às claras, em aberto.

A decadência, o decair, é a perda da tensão, tensão vital. É o relaxamento que faz com que a lassidão volte a imperar. É o desprender-se da margem para voltar a seguir o fluxo da correnteza. Nossa dificuldade está em não ver isso como carência, como algo negativo. Não se trata de nenhum moralismo, de corrigir a vida, buscar uma erradicação da decadência. Essa ânsia moralista é üßpı (hýbris), desmedida, é revolta contra a finitude. É querer apenas a luz, a evidência, o elevado, o próprio, desprezando o mistério, o que se vela, se oculta. O declínio de Zaratustra é como um sol que vai iluminar o mundo inferior, a escuridão da terra. É a escuridão da terra que abriga e nutre as raízes, sem a qual nada brota, nada vem à luz e dá frutos. A luz precisa da escuridão, luz e sombra se co-pertencem em uma mesma dinâmica. A máxima iluminação só se

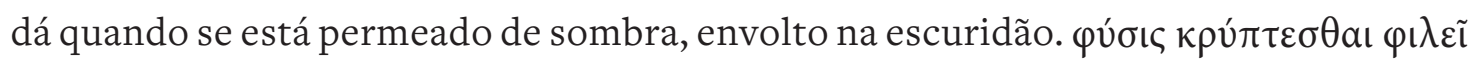
(phýsis krýptesthai philêi), "o vir à luz e o ocultar-se filiam-se"18.

Despreza-se o que se esconde porque sua conquista dá trabalho, é árdua, dolorosa. Almeja-se fugir da dinâmica de eterno retorno da reconquista da tensão vital. O frag-

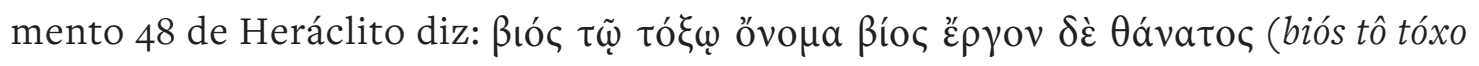
ónoma bíos érgon dè thánatos), arco ( $\beta$ ı́c): seu nome é vida (ßíoc) e sua obra é morte ${ }^{19}$.

17 NIETZSCHE, Assim falou Zaratustra, I, “Do ler e do escrever”, p. 48.

18 HERÁCLITO, fr.123, tradução proposta por E. Carneiro Leão, mimeo.

19 Tradução livre. 
O arco é, mudando a acentuação, vida. É a própria dinâmica de tensão e distensão - o acento que a define é o tonus, a tônica (força!), o tencionar, a tonalidade que a faz tal como é, faz a vida ser vida (filosofia). Largar mão, abrir mão dessa tensão é morte, é a seta que corre numa dinâmica oscilante, sempre mirando para baixo, não importando o quão alto se tenha mirado. Santo Agostinho vai dizer que o tempo é uma distensão da alma. Alma é vida. Nosso tempo linear é expresso pela flecha, atirada pela perda de tensão do arco da vida. A reconquista do próprio da vida é o salto para o eterno, o tempo divino, o qual nos é dado participar por um fugaz instante. Mas esse instante, por mais que se dê em um piscar de olhos, vale toda uma vida para quem vê, no pouco, plenitude, e não falta. “A grande superioridade da origem nobre é que pode suportar melhor a pobreza"2o.

Ser e tempo. Neste título essencial, a conjunção sobra. Não se trata de uma adição, ser + tempo. Trata-se de ser-tempo. Mas o tempo que somos e a cada vez devemos nos esforçar para ser é finito. Querer o finito, amar o finito, a margem. A isso Heidegger chama de pudor (die Scheu). Trata-se do silenciamento em meio ao mundo caótico do falatório e da curiosidade. É saber que a lida com o que é divino nunca é imediata. É a paciência de quem aprendeu que o ritmo do sagrado é o lento, ante a rapidez da vida. Resguardar para si o que necessita estar velado, preservar a sombra, o oculto, o mistério. A sanha de querer apenas a luz, de pôr tudo às claras, é um despudoramento. Vontade de verdade, isto é, vontade de luz, é coisa de despudorado, assanhado, sem-vergonha. É ưßpıs, desmedida. A medida é dada pelo Ser em seu mistério, que exige de nós um retraimento. Diante do mistério do ser que há muito havíamos nos esquecido, podemos ser capazes de nos dispormos com veneração diante do mistério, e sustentar o silêncio que a dominação expressa do falatório e da publicidade haviam obliterado. É isso o pudor: o respeito diante do sagrado e a sustentação do silêncio que a ele convém 


\section{REFERÊNCIAS BIBLIOGRÁFICAS}

AGAMBEN, Giorgio. O tempo que resta: um comentário à Carta aos Romanos. Trad. Davi Pessoa e Cláudio Oliveira. Belo Horizonte: Autêntica, 2016.

ANAXIMANDRO; PARMÊNIDES; HERÁCLITO. Os pensadores originários. Trad. Emmanuel Carneiro Leão e Sérgio Wrublewski. Petrópolis: Vozes, 2017 (Coleção Vozes de Bolso). ARISTÓTELES. Metafísica. Trad. Marcelo Perine. São Paulo: Loyola, 2002.

Bíblia Sagrada. Trad. Ivo Storniolo, Euclides Balancin e José Luiz do Prado. São Paulo: Paulus, 2000.

DIELS, Hermann; KRANZ, Walther. Die Fragmente der Vorsokratiker, vol. 1. Berlin: Weidmannsche, 1960.

HEMINGWAY, Ernest. O velho e o mar. Trad. Fernando de Castro Ferro. Rio de Janeiro: Bertrand, 2013.

HEIDEGGER, Martin. Marcas do Caminho. Trad. Enio Paulo Giachini e Ernildo Stein. Petrópolis: Vozes, 2008.

MACHADO DE ASSIS, J. Crônica de 26 de julho de 1896. Disponível em: http://www.cronicas.uerj.br/home/cronicas/machado/rio_de_janeiro/ano1896/26jul1896.html. Último acesso em: 23/10/2017.

NIETZSCHE, Friedrich. Assim falou Zaratustra. Trad. Paulo César de Souza. São Paulo: Companhia das Letras, 2011.

. Aurora. Trad. Mário Ferreira Santos. Petrópolis: Vozes, 2008.

Briefe. Werke in drei Bänden. Band 3, München, 1954.

PESSOA, Fernando. Poesia completa de Alberto Caeiro. São Paulo: Companhia das Letras, 2007. PLATÃO. Fedro. Trad. Carlos Alberto Nunes. Belém: Editora UFPA, 2011.

República. Trad. Maria Helena da Rocha Pereira. $13^{\mathrm{a}}$ ed. Lisboa: Fundação Calouste Gulbenkian, 2013.

ROSA, João Guimarães. Grande Sertão: Veredas. Rio de Janeiro: Nova Fronteira, 1986. 